\title{
Use of sweet lupin, canola oilcake and full-fat canola as alternatives to soybean oilcake in diets for broilers
}

\author{
T.S. Brand ${ }^{1,2, \#, ~ N . ~ S m i t h ², ~ L . C . ~ H o f f m a n ~}{ }^{2}$ \& L. Jordaan ${ }^{2}$ \\ ${ }^{1}$ Institute for Animal Production: Elsenburg, Western Cape Department of Agriculture, Private Bag X1, Elsenburg, 7607 , \\ South Africa \\ ${ }^{2}$ Department of Animal Sciences, University of Stellenbosch, Private Bag X1, Matieland, 7602, South Africa
}

(Received 20 January 2018; Accepted 13 June 2018; First published online 2 July 2018)

\begin{abstract}
Copyright resides with the authors in terms of the Creative Commons Attribution 4.0 South African License.
See: http://creativecommons.org/licenses/by/4.0/za

Condition of use: The user may copy, distribute, transmit and adapt the work, but must recognize the authors and the South African Journal of Animal Science.
\end{abstract}

\begin{abstract}
The effect of replacing soybean oilcake meal as a protein source with three levels $(6.6 \%, 13.0 \%$ and $20.0 \%$ ) of sweet lupin (Lupinus angustifolius), canola oilcake and full-fat canola in diets for broiler chickens was examined. A control diet with soybean oilcake as the protein source was supplemented with alternative test diets containing sweet lupin, canola oilcake or full-fat canola as protein source at $100.0 \%, 67.0 \%$ and $33.0 \%$ inclusion level. The test diets were fed for six weeks to determine their potential to enhance the nutritive value of these vegetable protein sources. Broiler weights at six weeks old were significantly higher for the control diet than the $20.0 \%$ lupin diet. The feed intake of the $20.0 \%$ canola oilcake diet at Week 6 was significantly less than that of the control diet, but not less than the $6.6 \%$ and $13.2 \%$ canola oilcake diets. The feed conversion ratio (FCR) of the control diet was better than the $13.2 \%$ and $20.0 \%$ canola oilcake diets. The FCR of the broilers fed the $13.2 \%$ and $20.0 \%$ full-fat canola diets was significantly poorer than the control diet. From this study it is clear that sweet lupin, canola oilcake meal and full-fat canola can be used at low inclusion levels to partially replace soybean oilcake meal as a protein source in broiler diets.
\end{abstract}

Keywords: Feed conversion ratio, poultry nutrition, protein concentrates

\# Corresponding author: tersb@elsenburg.com

\section{Introduction}

Protein sources are likely to become progressively more limiting and costly, owing to competition between feed ingredients for humans and monogastric animals (Florou-Paneri et al., 2014). Exploitation of the nutritional potential of all possible protein sources is therefore necessary. Sweet lupin (Lupinus albus and Lupinus angustifolius) is cultivated as a key legume crop in the winter rainfall region of South Africa, where it is estimated that 10000 tons are produced annually.

Although lupin is relatively high in crude protein (CP) (35.5\%) (Brand et al., 1995), problems could arise with its use in broiler diets because of the existence of anti-nutritional factors. Lupin may have undesirable levels of alkaloids (Erickson, 1985) and $\langle$-galactosides (90.0 g/kg) (Bourdon et al., 1987). Lupin has low starch content (0.3-0.5\%) (Cerning-Beroad \& Fillatre, 1976) and a high level of non-starch polysaccharides (NSP) (50.2\%) (Chesson, 1990), about 15.0\% of which is soluble (Annison et al., 1996).

The unrestricted use of canola meal as a high-quality protein supplement in poultry and other rapidly growing non-ruminant animals is limited by low available energy content. The metabolizable energy (ME) content of canola meal is approximately $8.4 \mathrm{MJ} / \mathrm{kg}$ for poultry. Total tract apparent protein digestibility in canola meal-based diets averages $74.0 \%$ in poultry (Thomke et al., 1983; Bell \& Keith, 1987). Inversely related to ME and protein contents are the fibre components of canola meal, which consist mainly of cellulose (4.0-6.0\%), non-cellulosic polysaccharides (13.0-16.0\%) and lignin, with associated polyphenols (8.0\%) (Simbaya et al., 1996; Kocher et al., 2000).

The objective of this study was to evaluate lupin, canola oilcake and full-fat canola as potential alternative protein sources to soybean oilcake meal in broiler diets. 


\section{Materials and methods}

Two mechanically ventilated broiler houses containing 30 floor pens each (60 pens in total) were used in this investigation. Each pen had four tube feeders and one automatic water drinker. The lighting programme was 24 hours bright light for the first three days and then 1 hour dimmed light (23 light/1 dark) to the end of the trial. The initial temperature under the brooders of each pen was $33^{\circ} \mathrm{C}$ and was gradually decreased to $22^{\circ} \mathrm{C}$ by day 28 .

Ross 308 broilers were used. Eighty-five broilers were randomly distributed to each of the 60 floor pens. The stocking density was 18 birds per $\mathrm{m}^{2}$. The ingredient compositions of the experimental diets are shown in Tables 1 and 2. The starter diets were formulated on an iso-nutrient basis to contain $13.0 \mathrm{MJ}$ $\mathrm{ME} / \mathrm{kg}$ feed and $20.5 \% \mathrm{CP}$. The grower/finishing diets were also formulated on an iso-nutrient basis to contain 13.4 MJ ME/kg feed and $18.5 \% \mathrm{CP}$.

Table 1 Ingredient compositions of starter diets (control diet containing soybean oilcake and alternative diets containing either full-fat canola, canola oilcake or sweet lupin) provided to broilers from hatching to 21 days old

\begin{tabular}{lcccc}
\hline \multirow{2}{*}{ Ingredient composition (kg/ton, as fed) } & \multicolumn{4}{c}{ Starter diets } \\
\cline { 2 - 5 } & Control & $\begin{array}{c}\text { Full-fat } \\
\text { canola }\end{array}$ & $\begin{array}{c}\text { Canola } \\
\text { oilcake }\end{array}$ & Sweet lupins \\
\hline Maize meal & 667.6 & 377.2 & 602.8 & 573.4 \\
Acid oil & 10.2 & 0.0 & 30.0 & 30.0 \\
Gluten 60 & 20.0 & 0.0 & 20.0 & 20.0 \\
Fish meal & 80.0 & 80.0 & 106.5 & 81.2 \\
Wheaten bran & 0.0 & 215.0 & 0.0 & 0.0 \\
Soybean oilcake & 193.1 & 103.6 & 20.0 & 64.7 \\
Full-fat canola & 0.0 & 200.0 & 0.0 & 0.0 \\
Canola oilcake & 0.0 & 0.0 & 200.0 & 0.0 \\
Sweet lupin (L. angustifolius) & 0.0 & 0.0 & 0.0 & 200.0 \\
Limestone & 12.3 & 11.3 & 10.0 & 12.2 \\
Monocalcium phosphorus & 8.9 & 6.6 & 4.8 & 8.9 \\
L-Lysine hydrochloride & 2.0 & 1.1 & 1.8 & 2.6 \\
DL Methionine & 2.2 & 2.1 & 1.4 & 3.3 \\
L-Threonine & 0.7 & 0.7 & 0.6 & 0.9 \\
Fine salt & 1.1 & 0.7 & 0.4 & 1.1 \\
Choline chloride & 0.9 & 0.7 & 0.7 & 0.7 \\
Vitamin \& mineral premix* & 1.0 & 1.0 & 1.0 & 1.0 \\
Calculated nutrient composition & & & & \\
Metabolizable energy (MJ/kg feed) & 13.00 & 13.00 & 13.00 & 13.00 \\
Crude protein (\%) & 20.50 & 20.50 & 20.50 & 20.50 \\
Lysine (\%) & 1.12 & 1.12 & 1.12 & 1.12 \\
Methionine (\%) & 0.54 & 0.53 & 0.53 & 0.58 \\
Total sulphur amino acids (\%) & 0.81 & 0.82 & 0.81 & 0.81 \\
Threonine (\%) & 0.74 & 0.74 & 0.74 & 0.74 \\
Tryptophan (\%) & 0.21 & 0.23 & 0.19 & 0.19 \\
Arginine (\%) & 1.06 & 1.14 & 0.93 & 1.25 \\
Calcium (\%) & 0.95 & 0.95 & 0.95 & 0.95 \\
Phosphorus (\%) & 0.45 & 0.45 & 0.45 & 0.45 \\
& & & & \\
\hline
\end{tabular}


Table 2 Ingredient compositions of grower/finishing diets (control diet containing soybean oilcake and alternative diets containing either full-fat canola, canola oilcake or sweet lupin) provided to broilers from 21 days old up to slaughtering at 42 days old

\begin{tabular}{|c|c|c|c|c|}
\hline \multirow{2}{*}{ Ingredient composition (kg/ton, as fed) } & \multicolumn{4}{|c|}{ Grower/Finishing diets } \\
\hline & Control & $\begin{array}{l}\text { Full-fat } \\
\text { canola }\end{array}$ & $\begin{array}{l}\text { Canola } \\
\text { oilcake }\end{array}$ & Sweet lupin \\
\hline Maize meal & 657.8 & 481.8 & 628.3 & 597.9 \\
\hline Acid oil & 37.8 & 0.0 & 0.0 & 45.0 \\
\hline Gluten 60 & 20.0 & 0.0 & 9.9 & 20.0 \\
\hline Fish meal & 30.0 & 30.0 & 98.2 & 62.9 \\
\hline Wheaten bran & 0.0 & 112.0 & 0.0 & 0.0 \\
\hline Soybean oilcake & 220.1 & 146.4 & 0.0 & 43.4 \\
\hline Full-fat canola & 0.0 & 200.0 & 0.0 & 0.0 \\
\hline Canola oilcake & 0.0 & 0.0 & 200.0 & 0.0 \\
\hline Sweet lupins (L. angustifolius) & 0.0 & 0.0 & 0.0 & 200.0 \\
\hline Limestone & 14.0 & 12.9 & 10.2 & 12.9 \\
\hline Monocalcium phosphorus & 11.0 & 9.1 & 3.4 & 8.4 \\
\hline L-Lysine hydrochloride & 2.3 & 1.3 & 1.3 & 2.5 \\
\hline DL Methionine & 2.0 & 1.9 & 1.0 & 2.8 \\
\hline L-Threonine & 0.8 & 0.7 & 0.4 & 0.9 \\
\hline Fine Salt & 2.5 & 2.2 & 0.6 & 1.6 \\
\hline Choline chloride & 0.7 & 0.7 & 0.7 & 0.7 \\
\hline Vitamin \& mineral premix* & 1.0 & 1.0 & 1.0 & 1.0 \\
\hline \multicolumn{5}{|l|}{ Calculated nutrient composition } \\
\hline Metabolizable energy (MJ/kg feed) & 13.40 & 13.40 & 13.40 & 13.40 \\
\hline Crude protein (\%) & 18.50 & 18.50 & 18.50 & 18.50 \\
\hline Lysine (\%) & 0.98 & 0.98 & 0.98 & 0.98 \\
\hline Methionine (\%) & 0.46 & 0.45 & 0.46 & 0.50 \\
\hline Total sulphur amino acids (\%) & 0.71 & 0.74 & 0.71 & 0.72 \\
\hline Threonine (\%) & 0.67 & 0.67 & 0.67 & 0.67 \\
\hline Tryptophan (\%) & 0.20 & 0.20 & 0.17 & 0.17 \\
\hline Arginine (\%) & 0.99 & 1.05 & 0.83 & 1.14 \\
\hline Calcium (\%) & 0.90 & 0.90 & 0.90 & 0.90 \\
\hline Phosphorus (\%) & 0.40 & 0.40 & 0.40 & 0.40 \\
\hline
\end{tabular}

*Standard poultry premix from ADVIT Animal Nutrition, Edenvale, Gauteng, South Africa

The experimental diets were blended to create four diets containing $6.6 \%, 13.2 \%$ and $20.0 \%$ of each of the alternative protein sources, as shown in Table 3. A sweet variety of $L$. angustifolius was used, and canola oilcake from a local oil processing plant. The full-fat canola was also produced locally.

Three replicate pens per treatment were used. The starter diet was fed from 1 day old to 21 days old and grower/finisher diet was fed up to 42 days old, when the birds were slaughtered. Birds were weighed and their feed intake calculated per pen at 1 day old and then every week until 42 days old. Regression analysis was performed on the inclusion rate of each protein source and the intercepts and slopes of the regression lines were compared by analysis of variance. Regression lines were done separately for the starter and grower periods. The effects of the inclusion rate of each of the protein sources were also compared by regression analysis. All procedures were described in detail by Statgraphics 5.1 (1991). 
Table 3 Composition of experimental diets containing different inclusion levels of either full-fat canola, canola oilcake or sweet lupin as alternative to a control diet containing soybean oilcake fed to the broiler chickens

\begin{tabular}{lll}
\hline Diet no & & Composition \\
\hline 1 & 100 lupin diet & $:$ 0 control diet (20.0\% lupin diet) \\
2 & 67 lupin diet & $: 33$ control diet (13.2\% lupin diet) \\
3 & 33 lupin diet & $: 67$ control diet (6.6\% lupin diet) \\
4 & 100 canola diet & $:$ 0 control diet (20.0\% canola oilcake diet) \\
5 & 67 canola diet & $: 33$ control diet (13.2\% canola oilcake diet) \\
6 & 33 canola diet & $: 67$ control diet (6.6\% canola oilcake diet) \\
7 & 100 full-fat canola diet & $:$ c control diet (20.0\% full-fat canola diet) \\
8 & 67 full-fat canola diet & $: 33$ control diet (13.2\% full-fat canola diet) \\
9 & 33 full-fat canola diet & $: 67$ control diet (6.6\% full-fat canola diet) \\
10 & control diet (Soybean oilcake diet) & \\
\hline
\end{tabular}

\section{Results and Discussion}

The effect of dietary lupin inclusion on broiler performance analysed by multifactor analysis of variance is presented in Table 4. Significant differences were detected in the broiler performance because of lupin inclusion in the diet. Differences $(P \leq 0.05)$ in the broiler weights were found at Week 3 and at six weeks old. The broiler weights (Week 3 ) at the 20.0\% lupin inclusion level were lower $(P \leq 0.05)$ compared with the $13.2 \%$ and $6.6 \%$ lupin diets and the control. At Week 6 the weight of the broilers fed the control diet was higher $(P \leq 0.05)$ than the weight of the broilers fed the $20.0 \%$ lupin diet. The feed intake (Week 3$)$ of the control diet was less $(P \leq 0.05)$ than the $13.2 \%$ and $20.0 \%$ lupin diets, but not significantly less than the $6.6 \%$ lupin diets. There were no significant differences in feed intakes at Week 6. The FCR (Week 3) became significantly poorer as the lupin content of the diets increased. The FCR of the $13.2 \%$ and $20.0 \%$ lupin diets (Week 6$)$ was poorer $(P \leq 0.05)$ when compared with the control and $6.6 \%$ lupin diet.

Table 4 Effect of dietary lupin inclusion on broiler performance

\begin{tabular}{lcccccccc}
\hline Treatment & \multicolumn{2}{c}{ Broiler weight $(\mathbf{k g})$} & \multicolumn{2}{c}{ Feed intake $\mathbf{( k g )}$} & $\begin{array}{c}\text { FCR (kg feed/kg } \\
\text { broiler weight gain) }\end{array}$ & Mortalities \\
\hline Age & Week 3 & Week 6 & Week 3 & Week 6 & Week 3 & Week 6 & Week 3 & Week 6 \\
Control & $0.74^{\mathrm{a}}$ & $2.09^{\mathrm{a}}$ & $0.99^{\mathrm{a}}$ & 3.60 & $1.35^{\mathrm{a}}$ & $1.72^{\mathrm{a}}$ & $3.56^{\mathrm{a}}$ & $6.22^{\mathrm{a}}$ \\
$6.6 \%$ lupin & $0.73^{\mathrm{a}}$ & $2.06^{\mathrm{ab}}$ & $1.02^{\mathrm{ab}}$ & 3.57 & $1.40^{\mathrm{b}}$ & $1.73^{\mathrm{a}}$ & $2.67^{\mathrm{b}}$ & $3.78^{\mathrm{b}}$ \\
$13.2 \%$ lupin & $0.73^{\mathrm{a}}$ & $2.05^{\mathrm{ab}}$ & $1.06^{\mathrm{b}}$ & 3.68 & $1.44^{\mathrm{c}}$ & $1.79^{\mathrm{b}}$ & $4.66^{\mathrm{c}}$ & $5.52^{\mathrm{c}}$ \\
$20.0 \%$ lupin & $0.68^{\mathrm{b}}$ & $1.96^{\mathrm{b}}$ & $1.04^{\mathrm{b}}$ & 3.64 & $1.54^{\mathrm{d}}$ & $1.85^{\mathrm{c}}$ & $4.67^{\mathrm{c}}$ & $6.67^{\mathrm{d}}$ \\
SEM & 0.01 & 0.04 & 0.01 & 0.09 & 0.02 & 0.06 & 0.28 & 0.49
\end{tabular}

${ }^{\mathrm{a}-\mathrm{d}}$ Column means with common superscripts do not differ $(P \leq 0.05)$

FCR: feed conversion ratio

These results suggest that the levels of alkaloids in the sweet lupin did not affect feed intake. Therefore, alkaloid levels in the sweet lupin were low enough not to cause negative effects in the broilers. The lower broiler weights were due to the poorer feed conversion ratios (FCRs) of those fed diets containing higher lupin levels. These poorer FCRs indicate that the broilers did not use the diets containing lupin as efficiently as the soybean meal diets. This is possibly because the broilers were not able to utilize the NSP in the lupin seeds. The slight increase in intake of the $13.2 \%$ lupin and $20.0 \%$ lupin diets may be due to lower energy availability of the diet and therefore the broilers consumed more to compensate for it.

At three weeks, the broilers fed the $6.6 \%$ lupin diet had significantly fewer mortalities compared with the other treatment groups, including the control. The groups fed the $13.2 \%$ and $20.0 \%$ lupin diets had 
similar mortality rates, but these were significantly greater compared with the control and $6.6 \%$ lupin-fed groups. This may indicate that high levels of lupin could influence the survival of broilers younger than three weeks old. At six weeks old, the mortalities of the $6.6 \%$ lupin and $13.2 \%$ lupin fed broilers were significantly lower compared with the control diet. This may indicate that broilers become more tolerant to the antinutritional factors in lupin. At $20.0 \%$ lupin inclusion in the diet, the mortalities were significantly higher compared with the control.

The results of the regression analysis conducted on the diets containing lupin in the starter phase are presented in Table 5. In the starter phase the slopes (b) of the regression lines of the ADG of the broilers fed the $20.0 \%$ lupin diet were significantly higher compared with the control, $6.6 \%$ and $13.2 \%$ lupin diets. The slopes (b) of the regression coefficients on feed intake were not significantly different for the control, 6.6\% and $13.2 \%$ lupin diet. The slope of the regression lines on FCR for the $13.2 \%$ lupin diet was the lowest. That is, it increased least in the starter period. This shows that the broilers could utilize the $13.2 \%$ lupin diet more effectively.

Table 5 Intercepts (a) and slopes (b) of the regression analysis on average daily gain, feed intake and feed conversion ratio of the broilers in the starter phase

\begin{tabular}{lcccccc}
\hline & \multicolumn{2}{c}{ Average Daily Gain } & \multicolumn{2}{c}{ Feed Intake } & \multicolumn{2}{c}{ Feed Conversion Ratio } \\
\cline { 2 - 7 } & $\mathbf{a}$ & $\mathbf{b}$ & $\mathbf{a}$ & $\mathbf{b}$ & $\mathbf{a}$ & $\mathbf{b}$ \\
\hline Control & $-0.004^{\mathrm{a}}$ & $0.019^{\mathrm{a}}$ & $-24.37^{\mathrm{a}}$ & $31.05^{\mathrm{a}}$ & $0.78^{\mathrm{b}}$ & $0.21^{\mathrm{b}}$ \\
$20.0 \%$ lupin & $-0.048^{\mathrm{d}}$ & $0.022^{\mathrm{b}}$ & $-75.29^{\mathrm{c}}$ & $32.98^{\mathrm{b}}$ & $0.70^{\mathrm{a}}$ & $0.22^{\mathrm{b}}$ \\
13.2\% lupin & $-0.016^{\mathrm{c}}$ & $0.020^{\mathrm{a}}$ & $-41.93^{\mathrm{b}}$ & $32.69^{\mathrm{a}}$ & $0.87^{\mathrm{d}}$ & $0.19^{\mathrm{a}}$ \\
6.6\% lupin & $-0.009^{\mathrm{b}}$ & $0.010^{\mathrm{a}}$ & $-24.54^{\mathrm{a}}$ & $31.68^{\mathrm{a}}$ & $0.84^{\mathrm{c}}$ & $0.22^{\mathrm{b}}$ \\
SEM & 0.010 & 0.001 & 11.98 & 0.45 & 0.04 & 0.01 \\
\end{tabular}

a-d Column means with common superscripts do not differ $(P \leq 0.05)$

The results of the regression analysis conducted on the diets containing lupin in the finisher phase are presented in Table 6. In the finisher phase, the slopes (b) of the regression lines on ADG of the broilers fed the $13.2 \%$ lupin diet were significantly smaller compared with the other treatments. The slopes of the regression lines on feed intake were similar, with no significant differences. The slopes of the regression lines on FCR for the $20.0 \%$ lupin diet were significantly lower. That is, they increased the least in the finisher period.

Whole seed lupin contains approximately $35.0 \%$ NSPs, of which $5.0 \%$ to $10.0 \%$ are soluble (Evans et al., 1993). In cereal grains, high levels of soluble NSPs increase digesta viscosity in the intestine of chickens, leading to reduced starch, protein and lipid digestion (Choct \& Annison, 1990; Annison \& Choct, 1991; Philip et al., 1995). The cell wall material of the lupin cotyledon is characterized by low cellulose content and high pectic substance content (Todorov et al., 1996). The main sugar component of cell wall material is galactose, followed by arabinose, fructose, xylanose and glucose (Carré et al., 1985). Steenfeldt et al. (2003) conducted a study to evaluate the effects of inclusion of lupin (Lupinus angustifolius) in broiler diets on production performance, digestibility and dietary apparent metabolizable energy. They found that the substitution of soybean meal and maize with lupin depressed weight gain and FCR significantly, but the feed intake of the lupin-based diets was not decreased. These results compare well with those in the current study.

In Table 7 significant differences are reported between the control diet and the diets containing canola oilcake. The broiler weights at Week 3 and Week 6 decreased significantly $(P \leq 0.05)$ as the canola oilcake content of the diets increased. At Week 3 the feed intake of the $20.0 \%$ canola oilcake diet was less $(P \leq 0.05)$ than the $6.6 \%$ and $13.2 \%$ canola oilcake and the control diet. The feed intakes at Week 6 differed $(P \leq 0.05)$ between the $20.0 \%$ canola oilcake diet and the control diet. This may explain the lower broiler weights of the birds fed the $20.0 \%$ canola oilcake diet. The FCR at Week 3 increased $(P \leq 0.05)$ with each increase in the canola oilcake content. At Week 6 the FCR of the $20.0 \%$ canola oilcake diet was significantly higher than the $6.6 \%$ and $13.2 \%$ canola oilcake diets and the control. The FCR of broilers at three weeks old became less efficient as the canola content increased, which proves that the broilers could not utilize the canola as well as the soybean meal control diet. This may be due to the cellulose $(4.0-6.0 \%)$, non-cellulosic 
polysaccharides (13.0-16.0\%) and lignin with associated polyphenols (8.0\%) (Simbaya et al., 1996; Kocher et al., 2000).

Broiler mortalities at three and six weeks old were significantly lower for the broilers receiving the diets containing canola oilcake, compared with those broilers fed the control diet.

Table 6 Intercepts (a) and slopes (b) of the regression analysis on average daily gain, feed intake and feed conversion ratio of the broilers in the finisher phase

\begin{tabular}{lcccccc}
\hline & \multicolumn{2}{c}{ Average Daily Gain } & \multicolumn{2}{c}{ Feed Intake } & \multicolumn{2}{c}{ Feed Conversion Ratio } \\
\cline { 2 - 7 } & $\mathbf{a}$ & $\mathbf{b}$ & $\mathbf{a}$ & $\mathbf{b}$ & $\mathbf{a}$ & $\mathbf{b}$ \\
\hline Control & 0.060 & $0.002^{\mathrm{c}}$ & $63.30^{\mathrm{b}}$ & 63.76 & $1.42^{\mathrm{a}}$ & $0.107^{\mathrm{b}}$ \\
20.0\% lupin & 0.057 & $0.002^{\mathrm{d}}$ & $-34.54^{\mathrm{a}}$ & 66.26 & $1.44^{\mathrm{a}}$ & $0.091^{\mathrm{a}}$ \\
13.2\% lupin & 0.060 & $0.001^{\mathrm{a}}$ & $66.37^{\mathrm{c}}$ & 65.48 & $1.49^{\mathrm{b}}$ & $0.106^{\mathrm{b}}$ \\
$6.6 \%$ lupin & 0.062 & $0.001^{\mathrm{b}}$ & $64.51^{\mathrm{b}}$ & 52.30 & $1.45^{\mathrm{a}}$ & $0.101^{\mathrm{b}}$ \\
SEM & 0.001 & 0.000 & 24.75 & 0.89 & 0.02 & 0.004 \\
\hline
\end{tabular}

${ }^{\mathrm{a}-\mathrm{d}}$ Column means with common superscripts do not differ $(P \leq 0.05)$

Table 7 Effect of dietary canola oilcake inclusion on broiler performance

\begin{tabular}{lcccccccc}
\hline Treatment & \multicolumn{2}{c}{ Broiler weight (kg) } & \multicolumn{2}{c}{ Feed intake (kg) } & $\begin{array}{c}\text { FCR (kg feed/kg } \\
\text { broiler weight gain) }\end{array}$ & Mortalities \\
\hline Age & Week 3 & Week 6 & Week 3 & Week 6 & Week 3 & Week 6 & Week 3 & Week 6 \\
Control & $0.74^{\mathrm{a}}$ & $2.09^{\mathrm{a}}$ & $0.99^{\mathrm{a}}$ & $3.60^{\mathrm{a}}$ & $1.35^{\mathrm{a}}$ & $1.72^{\mathrm{a}}$ & $3.56^{\mathrm{a}}$ & $6.22^{\mathrm{a}}$ \\
$6.6 \%$ canola oilcake & $0.68^{\mathrm{b}}$ & $1.94^{\mathrm{b}}$ & $0.99^{\mathrm{a}}$ & $3.47^{\mathrm{ab}}$ & $1.45^{\mathrm{b}}$ & $1.79^{\mathrm{ab}}$ & $2.44^{\mathrm{b}}$ & $3.33^{\mathrm{b}}$ \\
$13.2 \%$ canola oilcake & $0.63^{\mathrm{c}}$ & $1.75^{\mathrm{c}}$ & $0.97^{\mathrm{a}}$ & $3.32^{\mathrm{ab}}$ & $1.55^{\mathrm{c}}$ & $1.89^{\mathrm{b}}$ & $3.56^{\mathrm{a}}$ & $5.11^{\mathrm{c}}$ \\
$20.0 \%$ canola oilcake & $0.52^{\mathrm{d}}$ & $1.40^{\mathrm{d}}$ & $0.90^{\mathrm{b}}$ & $3.09^{\mathrm{b}}$ & $1.74^{\mathrm{d}}$ & $2.21^{\mathrm{c}}$ & $2.67^{\mathrm{c}}$ & $4.67^{\mathrm{c}}$ \\
SEM & 0.01 & 0.04 & 0.01 & 0.09 & 0.02 & 0.06 & 0.28 & 0.49 \\
\hline
\end{tabular}

${ }^{\mathrm{a}-\mathrm{d}}$ Column means with common superscripts do not differ $(P \leq 0.05)$

FCR: feed conversion ratio

The results of the regression analysis conducted on the diets containing canola oilcake in the starter phase are presented in Table 8. In the starter phase the slopes (b) of the regression lines on ADG of the broilers fed the diets containing canola oilcake decreased significantly as the canola oilcake inclusion increased. The slopes (b) of the regression lines on feed intake of the $20.0 \%$ canola oilcake diet were significantly lower compared with the other groups. The slopes (b) of the regression lines on feed intake of the rest of the treatments did not differ significantly. The slopes of the regression lines on FCR for the diets containing canola oilcake increased as the canola oilcake inclusion increased.

The results of the regression analysis conducted on the diets containing canola oilcake in the finisher phase are presented in Table 9. In the finisher phase the slopes (b) of the regression lines on ADG of the broilers were low. The slopes of the regression lines of the $13.2 \%$ and $20.0 \%$ canola oilcake diets were significantly greater compared with the other treatments. The slopes (b) of the regression lines on feed intake of the $20.0 \%$ and the $13.2 \%$ canola oilcake diets were significantly smaller compared with the control and the $6.6 \%$ canola oilcake diets. The slopes of the regression lines on FCR for the $20.0 \%$ canola oilcake containing diets were significantly greater compared with the other treatment groups. That is, FCR increased most for the $20.0 \%$ canola oilcake diets. This shows that the broilers were less efficient in utilizing the $20.0 \%$ canola oilcake containing diets. 
Table 8 Intercepts (a) and slopes (b) of regression analysis of average daily gain, feed intake and feed conversion ratio of the broilers in the starter phase

\begin{tabular}{|c|c|c|c|c|c|c|}
\hline & \multicolumn{2}{|c|}{ Average Daily Gain } & \multicolumn{2}{|c|}{ Feed Intake } & \multicolumn{2}{|c|}{ Feed Conversion Ratio } \\
\hline & $\mathbf{a}$ & b & a & b & a & b \\
\hline Control & $-0.004^{d}$ & $0.019^{d}$ & $-24.37^{\mathrm{b}}$ & $31.05^{\mathrm{b}}$ & $0.78^{\mathrm{a}}$ & $0.21^{\mathrm{a}}$ \\
\hline $20.0 \%$ canola oilcake & -0.002 & $0.013^{\mathrm{a}}$ & $-22.75^{a}$ & $28.76^{\mathrm{a}}$ & $0.82^{\mathrm{b}}$ & $0.35^{d}$ \\
\hline $13.2 \%$ canola oilcake & $-0.003^{c}$ & $0.016^{b}$ & $-22.83^{a}$ & $30.15^{\mathrm{b}}$ & $0.93^{\mathrm{c}}$ & $0.24^{c}$ \\
\hline $6.6 \%$ canola oilcake & $-0.002^{b}$ & $0.017^{\mathrm{c}}$ & $-25.05^{b}$ & $32.12^{b}$ & $0.82^{\mathrm{b}}$ & $0.24^{b}$ \\
\hline SEM & 0.009 & 0.001 & 0.57 & 0.71 & 0.03 & 0.03 \\
\hline
\end{tabular}

${ }^{\text {a-d }}$ Column means with common superscripts do not differ $(P \leq 0.05)$

Table 9 Intercepts (a) and slopes (b) of the regression analysis of average daily gain, feed intake and feed conversion ratio of the broilers in the finisher phase

\begin{tabular}{lcccccc}
\hline & \multicolumn{2}{c}{ Average Daily Gain } & \multicolumn{2}{c}{ Feed Intake } & \multicolumn{2}{c}{ Feed Conversion Ratio } \\
\cline { 2 - 7 } & $\mathbf{a}$ & $\mathbf{b}$ & $\mathbf{a}$ & $\mathbf{b}$ & $\mathbf{a}$ & $\mathbf{b}$ \\
\hline Control & $0.06^{\mathrm{d}}$ & $0.002^{\mathrm{a}}$ & $62.30^{\mathrm{b}}$ & $63.76^{\mathrm{b}}$ & $1.15^{\mathrm{a}}$ & $0.11^{\mathrm{b}}$ \\
$20.0 \%$ canola oilcake & $0.03^{\mathrm{a}}$ & $0.004^{\mathrm{d}}$ & $48.65^{\mathrm{a}}$ & $57.91^{\mathrm{a}}$ & $1.77^{\mathrm{d}}$ & $0.14^{\mathrm{c}}$ \\
$13.2 \%$ canola oilcake & $0.05^{\mathrm{b}}$ & $0.004^{\mathrm{c}}$ & $59.43^{\mathrm{b}}$ & $59.13^{\mathrm{a}}$ & $1.63^{\mathrm{c}}$ & $0.09^{\mathrm{a}}$ \\
$6.6 \%$ canola oilcake & $0.05^{\mathrm{c}}$ & $0.003^{\mathrm{b}}$ & $63.63^{\mathrm{b}}$ & $64.15^{\mathrm{b}}$ & $1.50^{\mathrm{b}}$ & $0.10^{\mathrm{b}}$ \\
SEM & 0.01 & 0.001 & 3.40 & 1.59 & 0.03 & 0.01 \\
\hline
\end{tabular}

${ }^{\mathrm{a}-\mathrm{d}}$ Column means with common superscripts do not differ $(P \leq 0.05)$

In a study by Kocher et al. (2001), the results indicated that high levels of canola meal could be included in broiler diets as the main dietary protein source in place of soybean meal without loss in bird performance. However, carcass yield and quality would be reduced. A study by Leeson et al. (1987) showed that canola meal could replace up to $100 \%$ of dietary soybean meal without major negative effects on performance, energy or mineral utilization, provided lysine was added as the limiting amino acid. However, the low level of available energy, reduced levels of CP and lysine, and increased levels of indigestible carbohydrates of canola meal compared with soybean meal (Bell, 1993) make canola meal a less competitive alternative when used at high levels in broiler diets.

The effect of full-fat canola on the performance of broilers is summarized in Table 10. Broiler weights at Week 3 were significantly lower $(P \leq 0.05)$ for the $20.0 \%$ full-fat canola diet compared with the $6.6 \%$ and 13.2\% full-fat canola diets, and the control. Feed intakes were significantly lower $(P \leq 0.05)$ for the control and $20.0 \%$ full-fat canola diet at Week 3 , a possible explanation for the reduced broiler weight. At Week 6 , broiler weight and feed intake did not differ significantly $(P \leq 0.05)$ among treatments. The FCR of the control diet at Week 3 was significantly lower $(P \leq 0.05)$ than those of the other treatments. However, at Week 6 the FCR of the control diet and the $6.6 \%$ full-fat canola diet did not differ significantly, but the FCR of the control diet was significantly lower $(P \leq 0.05)$ than that of the $13.2 \%$ and $20.0 \%$ full-fat canola diets. The higher FCRs of the broilers fed the full-fat canola diets show reduced efficiency in the utilization of the full-fat canola diets. This effect was much more drastic at three weeks old than at six weeks old. In a study by Shires et al. (1987) broilers fed canola-based diets had gastrointestinal tracts that were much heavier than broilers fed soybean meal diets. Increased weight of the gastrointestinal tract is associated with longer digestive organs as a result of increased digestion of the more fibrous canola-based diets. The increase in size of the gastrointestinal tract takes time to achieve. Therefore, older broilers may have the ability to cope with higher fibre diets, which may explain the difference in the results at three and six weeks old.

At three weeks old the broilers fed the $6.6 \%$ full-fat canola diet had the same mortality rate as the control. Broilers receiving the $13.2 \%$ full-fat canola diet had a significantly lower mortality rate compared with the other treatments, including the control. However, at $20.0 \%$ full-fat canola inclusion the mortalities were 
significantly greater compared with the other treatments. At six weeks old the $6.6 \%$ full-fat canola group had a significantly higher mortality rate compared with the other groups. The $13.2 \%$ and $20.0 \%$ full-fat canola groups had a significantly lower mortality rate compared with the other groups. From these results it is unlikely that the full-fat canola had an influence on the mortality rate.

Table 10 Effect of full-fat canola on the performance of broilers

\begin{tabular}{|c|c|c|c|c|c|c|c|c|}
\hline \multirow{2}{*}{$\begin{array}{l}\text { Treatment } \\
\text { Age }\end{array}$} & \multicolumn{2}{|c|}{$\begin{array}{c}\text { Broiler weight } \\
(\mathrm{kg})\end{array}$} & \multicolumn{2}{|c|}{$\begin{array}{c}\text { Feed intake } \\
(\mathrm{kg})\end{array}$} & \multicolumn{2}{|c|}{$\begin{array}{c}\text { FCR ( } \mathrm{kg} \text { feed/kg } \\
\text { broiler weight gain) }\end{array}$} & \multicolumn{2}{|c|}{ Mortalities } \\
\hline & Week 3 & Week 6 & Week 3 & Week 6 & Week 3 & Week 6 & Week 3 & $\begin{array}{l}\text { Week } \\
\quad 6\end{array}$ \\
\hline Control & $0.74^{\mathrm{a}}$ & 2.09 & $0.99^{\mathrm{a}}$ & 3.60 & $1.35^{\mathrm{a}}$ & $1.72^{\mathrm{a}}$ & $3.56^{\mathrm{a}}$ & $6.22^{\mathrm{a}}$ \\
\hline $6.6 \%$ full-fat canola & $0.74^{\mathrm{a}}$ & 2.08 & $1.05^{\mathrm{b}}$ & 3.66 & $1.42^{b}$ & $1.75^{\mathrm{ab}}$ & $3.56^{\mathrm{a}}$ & $8.22^{b}$ \\
\hline $13.2 \%$ full-fat canola & $0.73^{\mathrm{a}}$ & 2.05 & $1.04^{b}$ & 3.62 & $1.42^{b}$ & $1.79^{b}$ & $2.43^{b}$ & $3.32^{c}$ \\
\hline $20.0 \%$ full-fat canola & $0.68^{b}$ & 2.00 & $2.00^{\mathrm{a}}$ & 3.60 & $1.47^{\mathrm{b}}$ & $1.80^{\mathrm{b}}$ & $4.22^{c}$ & $5.33^{d}$ \\
\hline SEM & 0.01 & 0.04 & 0.01 & 0.09 & 0.02 & 0.06 & 0.28 & 0.49 \\
\hline
\end{tabular}

${ }^{\mathrm{a}-\mathrm{d}}$ Column means with common superscripts do not differ $(P \leq 0.05)$

FCR: feed conversion ratio

The results of the regression lines conducted on the diets containing full-fat canola in the starter phase are presented in Table 11. In the starter phase the slopes (b) of the regression lines on ADG did not differ significantly, with the exception of the $20.0 \%$ full-fat canola, which had a significantly greater slope. The slopes (b) of the regression lines on feed intake of the $13.2 \%$ full-fat canola diet were significantly greater compared with the other treatment groups. The slopes (b) of the regression lines on FCR for the full-fat canola diets increased as the full-fat canola inclusion increased.

Table 11 Intercepts (a) and slopes (b) of the regression analysis of average daily gain, feed intake and feed conversion ratio of the broilers in the starter phase

\begin{tabular}{lcccccc}
\hline & \multicolumn{2}{c}{ Average Daily Gain } & \multicolumn{2}{c}{ Feed Intake } & \multicolumn{2}{c}{ Feed Conversion Ratio } \\
\cline { 2 - 7 } & $\mathbf{a}$ & $\mathbf{b}$ & $\mathbf{a}$ & $\mathbf{b}$ & $\mathbf{a}$ & $\mathbf{b}$ \\
\hline Control & $-0.004^{\mathrm{a}}$ & $0.019^{\mathrm{a}}$ & $-24.37^{\mathrm{a}}$ & $31.05^{\mathrm{a}}$ & $0.78^{\mathrm{a}}$ & $0.21^{\mathrm{a}}$ \\
$20.0 \%$ full-fat canola & $-0.017^{\mathrm{c}}$ & $0.028^{\mathrm{b}}$ & $-24.84^{\mathrm{a}}$ & $31.20^{\mathrm{a}}$ & $0.84^{\mathrm{c}}$ & $0.25^{\mathrm{c}}$ \\
$13.2 \%$ full-fat canola & $-0.005^{\mathrm{b}}$ & $0.020^{\mathrm{a}}$ & $-26.24^{\mathrm{b}}$ & $33.42^{\mathrm{b}}$ & $0.83^{\mathrm{b}}$ & $0.23^{\mathrm{b}}$ \\
$6.6 \%$ full-fat canola & $-0.004^{\mathrm{b}}$ & $0.020^{\mathrm{a}}$ & $-25.02^{\mathrm{a}}$ & $32.63^{\mathrm{a}}$ & $0.85^{\mathrm{c}}$ & $0.22^{\mathrm{ab}}$ \\
SEM & 0.003 & 0.002 & 0.40 & 0.57 & 0.02 & 0.01 \\
\hline
\end{tabular}

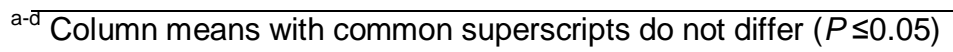

The results of the regression analysis conducted on the full-fat canola containing diets in the finisher phase are presented in Table 12. In the finisher phase the slopes (b) of the regression lines on ADG differed significantly, with the $13.2 \%$ full-fat canola diet regression line having a significantly smaller slope. The slopes (b) of the regression lines on feed intake did not differ significantly among the treatment groups, with the exception of the $20.0 \%$ full-fat canola diet. The smaller slope of the feed intake regression of this group may explain the significantly smaller slope of the ADG. The slopes of the regression lines on FCR for the $20.0 \%$ full-fat canola containing diets were significantly smaller. The slopes of the $20.0 \%$ full-fat canola diets were significantly smaller compared with the slopes of the control treatments. 
Table 12 Intercepts (a) and slopes (b) of the regression analysis of average daily gain, feed intake and feed conversion ratio of broilers in the finisher phase

\begin{tabular}{lcccccc}
\hline & \multicolumn{2}{c}{ Average Daily Gain } & \multicolumn{2}{c}{ Feed Intake } & \multicolumn{2}{c}{ Feed Conversion Ratio } \\
\cline { 2 - 7 } & a & b & a & b & a & b \\
\hline Control & $0.060^{\mathrm{a}}$ & $0.002^{\mathrm{d}}$ & $62.30^{\mathrm{a}}$ & $63.76^{\mathrm{a}}$ & $1.42^{\mathrm{a}}$ & $0.11^{\mathrm{c}}$ \\
$20.0 \%$ full-fat canola & $0.067^{\mathrm{b}}$ & $-0.001^{\mathrm{b}}$ & $60.98^{\mathrm{a}}$ & $62.80^{\mathrm{a}}$ & $1.54^{\mathrm{b}}$ & $0.09^{\mathrm{a}}$ \\
$13.2 \%$ full-fat canola & $0.067^{\mathrm{b}}$ & $-0.002^{\mathrm{a}}$ & $68.36^{\mathrm{b}}$ & $66.52^{\mathrm{a}}$ & $1.47^{\mathrm{a}}$ & $0.11^{\mathrm{c}}$ \\
$6.6 \%$ full-fat canola & $0.061^{\mathrm{a}}$ & $0.001^{\mathrm{c}}$ & $66.62^{\mathrm{b}}$ & $63.93^{\mathrm{a}}$ & $1.48^{\mathrm{a}}$ & $0.10^{\mathrm{b}}$ \\
SEM & 0.003 & 0.001 & 1.75 & 0.80 & 0.03 & 0.01 \\
\hline
\end{tabular}

${ }^{\mathrm{a}-\mathrm{d}}$ Column means with common superscripts do not differ $(P \leq 0.05)$

Leeson et al. (1987) found that increasing the dietary proportion of full-fat canola significantly reduced feed intake and weight gain, without altering the feed/gain ratio. Their results were congruent with earlier results, which showed a decrease in feed intake and weight gain with increasing dietary amounts of full-fat canola. Nwokolo \& Sim (1989) conducted a study in which wheat and barley were partially replaced in broiler diets, and found that broilers fed the full-fat canola diet had significantly lower weight gains compared with the wheat and barley diets. Feed intake and FCR were not affected. The non-starch polysaccharide content of canola was $179.0 \mathrm{~g} / \mathrm{kg}$ (Bell, 1993) and, as for the lupin, it could be an explanation for the significant $(P$ $\leq 0.05)$ differences in the six-week broiler weights.

A comparison of the effects of the inclusion rates of the various protein sources on broiler weight at three weeks old revealed that a linear model best fits the decrease in broiler starter weight (hatching up to 21 days old) because of the replacement of soybean oilcake with canola oilcake. For each percentage increase in canola oilcake inclusion, broiler starter weight decreased by $1.1 \mathrm{~g}$. The replacement of soybean oilcake with lupin and full-fat canola in the broiler diets decreased broiler starter weight (hatching up to 21 days old) according to the best-fit curvilinear model. As the level of inclusion of lupin and full-fat canola increased in the broiler diets, the broiler starter weight decreased.

A comparison of the effects of the inclusion rates of the various protein sources on broiler weight at six weeks old (finisher stage) revealed that during the finisher phase broiler slaughter weight decreased linearly when soybean oilcake was replaced with lupin, full-fat canola and canola oilcake. Broiler slaughter weight decreased as the inclusion rate of lupin, full-fat canola and canola oilcake increased.

The effects of the inclusion of the alternative protein sources on feed intake during the starter phase showed that the feed intakes of the broiler diets decreased curvilinearly as the inclusion rates of lupin, full-fat canola and canola oilcake increased. Canola oilcake showed the greatest decrease in feed intake.

The effect of the inclusion of the alternative protein sources on the feed intake during the finisher phase decreased linearly when soybean oilcake was replaced with canola oilcake. During the finisher phase the FCR increased linearly when soybean oilcake was replaced with full-fat canola and lupin. The FCR increased curvilinearly as the inclusion rate increased when soybean oilcake was replaced with canola oilcake.

\section{Conclusion}

Soybean oilcake could be replaced partially with sweet lupin up to $13.2 \%$ of the diet, without significant reductions in broiler performance. Replacing soybean oilcake meal with canola oilcake reduced the growth performance of broilers at a $6.6 \%$ inclusion level, resulting in a significantly higher FCR. The replacement of soybean oilcake meal with full-fat canola oilcake reduced broiler performance only at the $20.0 \%$ inclusion level, but at lower inclusion levels the broiler performance was not influenced significantly. Thus, sweet lupin, full-fat canola and canola oilcake meal could be used as alternatives, if provided at the recommended inclusion levels. The use of these locally produced alternative protein sources that were investigated in this study would depend mainly on the availability and price of these raw materials.

\section{Acknowledgements}

Acknowledgements are made to Western Cape Department of Agriculture for joint funding of the study, and the personnel in their employment for their aid, and also to Western Cape Agricultural Research Trust for joint funding of the study. 


\section{Authors' contributions}

Concept and design: TSB; data collection and analysis: NS; drafting of paper: LJ; critical revision and final approval of version to be published: LCH. This statement is to certify that all the authors of this paper made substantial contributions to conception and design, acquisition of data, and analysis and interpretation of data. All the authors have seen and approved the manuscript being submitted.

\section{Conflict of Interest declaration}

The authors certify that they have no affiliations with or involvement in any organization or entity with financial or non-financial interests in the subject matter and materials discussed in this manuscript.

\section{References}

Annison, G. \& Choct, M., 1991. Anti-nutritive activities of cereal non-starch polysaccharides in broiler diets and strategies minimizing their effects. World's Poult. Sci. J. 47, 232-242.

Annison, G., Hughes, R.J. \& Choct, M., 1996. Effects of enzyme supplementation on the nutritive value of dehulled lupins. Br. Poult. Sci. 37, 157-172.

Bell, J.M., 1993. Factors affecting the nutritive value of canola meal: A review. Can. J. Anim. Sci. 73, 679-697.

Bell, J.M. \& Keith, M.O., 1987. Feeding value for pigs of canola meal derived from Westar and Triazine tolerant cultivars. Can. J. Anim. Sci. 67, 811-819.

Bourdon, D., Fevrier, C., Leclercq, B., Lessire, M. \& Perez, J.M., 1987. Comments on raw materials. In: J. Wiseman (ed). Feeding of non-ruminant livestock. Butterworths, London. pp. 123.

Brand, T.S., Olckers, R.C. \& Van der Merwe, J.P., 1995. Evaluation of faba beans (Vicia faba cv. Fiord) and sweet lupin (Lupinus albus cv. Kiev) as protein sources for growing pigs. S. Afri. J. Anim. Sci. 25, 31-35.

Carré, B., Brillouet, J-M. \& Thibault, J-F., 1985. Characterization of polysaccharides from white lupins (Lupinus albus) cotyledon. J. Agric. Food Chem. 33, 285-292.

Cerning-Beroad, J. \& Filiatre, A. 1976. A comparison of the carbohydrate composition of legume seed: Horse-beans, peas and lupin. Cereal Chem. 53, 968. (cited by Brand et al., 1995).

Chesson, A., 1990. Nutritional significance and nutritive value of plant polysaccharides. In: J. Wiseman, \& D.J.A. Cole (eds). Feedstuff evaluation. Butterworths, London. pp. 179.

Choct, M. \& Annison, G., 1990. Anti-nutritive activity of wheat pentosans in broiler diets. Br. Poult. Sci. 31, 811-821.

Erickson, J.P., 1985. Lupins show potential as protein source for livestock. Feedstuffs 57, 22.

Evans, A.J., Cheung, P.C.K. \& Cheetman, N.W.H., 1993. The carbohydrate composition of cotyledons and hulls of cultivars of Lupinus angustiflius from Western Australia. J. Sci. Food Agric. 61, 189-194. (cited by Pettersen, 1998).

Florou-Paneri, P., Christaki, E., Giannenas, I., Bonos, E., Skoufos, I., Tsinas, A., Tzora, A., \& Peng, J. 2014. Alternative protein sources to soybean meal in pig diets. J. Food Agric. Environ. 12, 655-660.

Kocher, A., Choct, M., Poter, M.D. \& Broz, J., 2000. The effects of enzyme addition to broiler diets containing high concentrations of canola or sunflower meal. Poult. Sci. 79, 1767-1774.

Kocher, A., Choct, M., Morrisroe, L. \& Broz, J., 2001. Effects of enzyme supplementation on the replacement value of canola meal for soybean meal in broiler diets. Aust. J. Agric. Res. 52, 447-452.

Leeson, S., Atteh, J.O. \& Summer J.D., 1987. The replacement value of canola meal for soybean meal in poultry diets. Can. J. Anim. Sci. 67, 151-158.

Nwokolo, E. \& Sim, J., 1989. Barley and full-fat canola seed in broiler diets. Poult. Sci. 68, 1374-1380.

Philip, J.S., Gilbert, H.J. \& Smithard, R.R., 1995. Growth, viscosity and beta-glucanase activity of intestinal fluid in broiler chickens fed on barley-based diets with or without exogenous beta-glucanase. Br. Poult. Sci. 36, 599-603.

Shires, A., Thompson, J.R., Turner, B.V., Kennedy, P.M. \& Goh, Y.K., 1987. Rate of passage of corn-canola meal and corn-soybean meal diets through the gastrointestinal tract of broiler and White Leghorn chickens. Poult. Sci. 66 (2), 289-298.

Simbaya, J., Slominski, B.A., Geunter, W., Morgan, A. \& Campbell, L.D., 1996. The effects of protease and carbohydrase supplementation on the nutritive value of canola meal for poultry: In vitro and in vivo studies. Anim. Feed Sci. Tech. 61, 219-234.

Statgraphic 5.0, 1991. Statistical graphic system. Statistical Graphic Corporation Inc., 2115 East Jefferson Street, Rockville MD, 20852. pp. 015-033.

Steenfeldt, S., Gonzalez, E. \& Knudsen, K.E.B., 2003. Effects of inclusion of lupins (Lupinus angustifolius) in broiler diets and enzyme supplementation on production performance, digestibility and dietary apparent metabolisable energy content. Anim. Feed Sci. Technol. 110, 185-200.

Thomke, S., Elwinger, K., Rundgren, M. \& Ahlstrom, B., 1983. Rapeseed meal of Swedish low glucosinolate type fed to broiler chickens, laying hens and growing-finishing pigs. Acta Agric. Scand. 33, 75-96. (cited by Simbaya et al., 1996).

Todorov, M.A., Pavlov, D.C. \& Kostoy, K.D., 1996. Lupin (Lupinus spp.). In: E. Nwokolo \& J. Smartt (eds). Food and Feed from Legumes and Oilseeds. Chapman \& Hall, London. pp. 113. 